\title{
The Relation of Root to Stem in Calamites.
}

\author{
BY \\ ARTHUR J. MASLEN, F.L.S. \\ With Plates I and II, and a Figure in the Text.
}

INTRODUCTION.

THE identity of Williamson's genus Astromyelon with the roots of Scott ${ }^{2}$.

Casts and impressions of Calamitean stems showing attached adventitious roots have often been figured and described. Lindley and Hutton figure in their 'Fossil Flora of Great Britain ${ }^{3}$ ' specimens with roots inserted just above the nodes of the stem, and one of Grand' Eury's figures, which is reproduced by Seward in his textbook ${ }^{4}$, shows three nodes each with adventitious roots inserted either at or immediately above them. Weiss also gives good figures of Calamitean stems with attached roots, and some of these show clearly the continuity of the central cylinder of the roots with the vascular bundles of the stem at the node ${ }^{5}$.

Renault also figures roots inserted on the nodes of the stem ${ }^{6}$.

In most cases the roots arise in whorls, but according to Weiss they are sometimes grouped in tufts which arise close to the insertion of the lateral branches ${ }^{7}$.

So much has long been known, but, nevertheless, much difference of opinion has been expressed with reference to the exact mode of attachment of the roots to the stems.

In Equisetum, with which it is natural to compare Calamites, the adventitious roots arise from the base of the lateral branches, one

1 Nouvelles recherches sur le genre Astromyelon, Mém. de la Soc. des Sci. Nat. de Saône-etLoire, $\mathrm{I} 885$.

2 Further Observations on the Organization of the Fossil Plants of the Coal-Measures, Part II The Roots of Calamites, Phil. Trans., vol. I 86, B. I 895 .

${ }^{3}$ Vol. I, Plates LXXVIII and LXXIX. $\quad{ }^{4}$ Fossil Plants, vol. i, Fig. 77, p. 3 I6.

5 Steinkohlen-Calamarien, Abhandlungen zur geologischen Specialkarte von Preussen, I884, Part II, Pl, 2.

6 Renault and Zeiller, Flore houillère de Commentry, Part II, Pl. LVII, Fig. I.

7 Loc. cit., Part II, Plates VIII and IX.

[Annals of Botany, Vol. XIX. No. LXXIII. January, 1905.] 
(sometimes more) on each branch. Each bud usually produces a single root below the first leaf-sheath and from the lower side of the branch. In the aerial shoots the roots usually abort, but from the buds formed on the rhizome the roots develop whether the buds themselves grow farther or not'. In Calamites we can discover no trace of these 'rhizophoric buds': the roots pass right through the wood of the main stem and are directly connected with its primary xylem.

Many observers have tried to show that the roots of Calamites were in some way connected with the infra-nodal organs of Williamson. Thus Renault states that: 'Les racines adventives, quand elles se développaient, étaient en rapport avec ces organes que nous considérons comme des organes particuliers expectants, que nous distinguerons sous le nom d'organes rhizifères 2.' Again, in describing a specimen of his Arthropitus lineata exhibiting some large roots, he says: 'Les racines avortées ne sont représentées que par les organes rhizifères dont nous avons déjà plusieurs fois parlé; dans l'échantillon qui nous occupe ces organes sont bien conservés; ils sont dirigés du centre à la périphérie en s'abaissant un peu dans leur course; leur section transversale est elliptique; ils sont nettement formés d'une partie centrale composée de cellules polyédriques à minces parois, et d'une gaine de cellules prismatiques allongées dans le sens de l'organe et dont les parois portent de nombreuses ponctuations; là où les racines se sont développées les organes rhizifères n'existent plus ${ }^{3}$ ''

The 'organes rhizifères' of Renault are certainly the same as Williamson's infra-nodal organs, as Renault himself agrees ${ }^{4}$. Jeffrey, following Renault, and comparing the Calamites with their modern representatives, goes so far as to state that the more conspicuous series of nodules on casts of Calamites are not impressions of infra-nodal canals, but of the short cylindrical medullary cavities of modified rhizophorous branches, homologous with those of Equiseta ${ }^{5}$, i. e. with the little developed buds from which many of the roots of the rhizome arise, and described by Jeffrey as 'rhizophoric buds.'

Grand' Eury ${ }^{6}$ has recently described the distribution of the infranodal tubercles on the stems of Calamites, and he states that they are absent on the horizontal rhizomes and occur only on the ascending portions of the subterranean stems. If this account of their distribution is correct, their absence from the rhizomes is difficult to account for on the assumption that they are rhizophorous.

1 Campbell, Mosses and Ferns, p. 447.

${ }^{2}$ Flore fossile du bassin houiller et permien d'Autun et d'Épinac, Part II (text), r896, p. 89. Published in Études des Gîtes Minéraux de la France.

${ }^{3}$ Loc. cit., p. 106.

${ }^{4}$ Loc. cit., Flore fossile d'Autun, Part II, p. 89.

$5 \mathrm{Mem}$. Bost. Soc. Nat. Hist., vol. v, No. 5 , I 899, p. 188.

${ }^{6}$ Forêt fossile de Calamites Suckowii, Comptes Rendus, $189 \%$. 
More recently, and after an examination of some of the sections described later in this paper, and of Renault's specimens in Paris, Jeffrey contradicted his previous statements and declared that: 'It is apparent from these recent observations that there is no necessary relation between the presence of roots and the occurrence of infra-nodal tubercles,' and that the roots were not attached to them although they were present in abundance in the same specimens ${ }^{1}$. He thus comes to a conclusion which was long ago arrived at by Williamson. Detailed examination of the large series of slides on which the present paper is based, many of them showing infra-nodal organs and roots in the same slide, confirms Williamson's conclusion that there is no connexion between these two sets of organs. The infra-nodal organs are always distinctly below the nodes and pass right through to the pith of the stem: the adventitious roots are inserted about on a level with the nodes (i. e. the level of the leaf-traces), and can also be traced right through to their connexion with the primary xylem of the stem. At no point in their course are the two sets of organs connected with one another. Indeed, the functions and homology of the infra-nodal organs remain as great a mystery as ever.

The principal object of the present paper is to describe and illustrate some recently obtained specimens and sections of the basal part of the stem of Calamites in which the connexion with the roots is clearly shown. Renault has already figured specimens with Astromyelon structures on Calamitean stems, and has shown that similar appendages were borne on the stems of the sub-genera Bornia (Archaeocalamites) and Calamodendron ${ }^{2}$, as well as on those of Arthropitys (Göppert), the form to which most of the petrified Calamitean stems in the British Coal-Measures may be referred. Specimens showing the connexion between stem and root, and also exhibiting structure, are rare in our British collections of fossil plants. Williamson and Scott in their memoir on "The Roots of Calamites ${ }^{3}$ " only instance one example in the Williamson Collection, and Seward in his textbook ${ }^{4}$ figures one other example from a section in the Cambridge Botanical Laboratory Collection.

The reason for the paucity of such sections is doubtless to be found in the fact that all the largest roots, as far as is at present known, were adventitious and only occurred at the base of the main aerial stems and on the underground rhizomes, while most of the fragments of Calamitean stems which are found represent portions of the axis above the root region.

All the sections have been skilfully prepared by Mr. James Lomax of Bolton, and all were in the possession of Dr. D. H. Scott, F.R.S.,

1 Annals of Botany, vol. xv, I90r, pp. I39-140.

2 Luc. cit., Flore fossile d'Autun, Part II (Atlas), Plates XLIII and LIX.

${ }^{3}$ Loc. cit., p. $685 . \quad{ }^{4}$ Fossil Plants, vol. i, Fig. 92, p. 347. 
by whom they were given to me for examination. Some of the slides have now been incorporated in Dr. Scott's collection and are indicated by the letter $S$ in the following description; the others, marked M, are now in my own collection.

\section{Description of the SPECIMENS.}

The specimen shown in Plate I, Fig. I, was contained in the collection of the Chadwick Museum, Bolton, and for the photograph we are indebted to the curator, Mr. W. W. Midgley, F.R.Met.S. A series of twelve sections has been made from the specimen by Mr. Lomax (slides $\mathrm{IO}_{2}-\mathrm{IIO}_{3} \mathrm{~S}$ ).

It measures just over seven inches in length, and tapers at its lower end almost to a point, and so comes to resemble in form the familiar medullary casts of the branches of Calamitean stems. It is not, however, a mere medullary cast, as the sections which have been made from the specimen clearly show the internal structure of the wood. Passing right through the xylem from its inner border outwards are seen in the sections a considerable number of adventitious roots arranged in whorls, from four to six from a node. The arrows in the photograph indicate the position of these whorls of roots, each of which is visible on the outside of the specimen as a distinct elevation. The lower tapering part of the stem is about three inches long, and on this portion the whorls of adventitious roots are crowded together. In the upper four inches there is only one whorl of roots. Some of the roots show an evidently fractured surface (see the middle node of the tapering part of Fig. I), indicating that they have been broken off subsequently to fossilization.

It would appear that we here have the lowest part of a main aerial stem of Calamites, obviously in a young condition from its comparatively small size. The way in which the root tapers below to a blunt point would indicate the absence of a persistent primary root and that all its roots were adventitious. Probably the lower tapering part and some of the stem above were embedded in the swampy soil in which the plants grew, and it was propped up by its whorls of adventitious roots in very much the same way as in some Monocotyledons at the present day. As it is known that Calamites was provided with an underground rhizome from which the erect stems grew, it is highly probable that our specimen was attached at its narrow end to such a rhizome. If so the attachment must have remained a small one. This is of course quite different from the familiar cases of the attachment of pith-casts of branches of stems or rhizomes by little more than points. Williamson long ago explained the latter by showing that, although the pith became very narrow at the junction of branch and stem or of one branch with another, the enclosing secondary wood became much thicker, so that the real attachment was 
not narrow but broad. In our specimen the wood also is preserved, and the real area of attachment to the rhizome must have been a small one. After leaving the rhizome the pith and wood rapidly dilated.

Passing to the sections which have been cut from this specimen it is unfortunate that the preservation of the tissues is peculiar and not good. The hollow pith-cavity has been filled with sand and the inner part of the wood has been to a certain extent destroyed. Some of the xylem wedges which project into the pith-cavity are however complete, and they show their carinal canals quite clearly and sufficient to demonstrate the

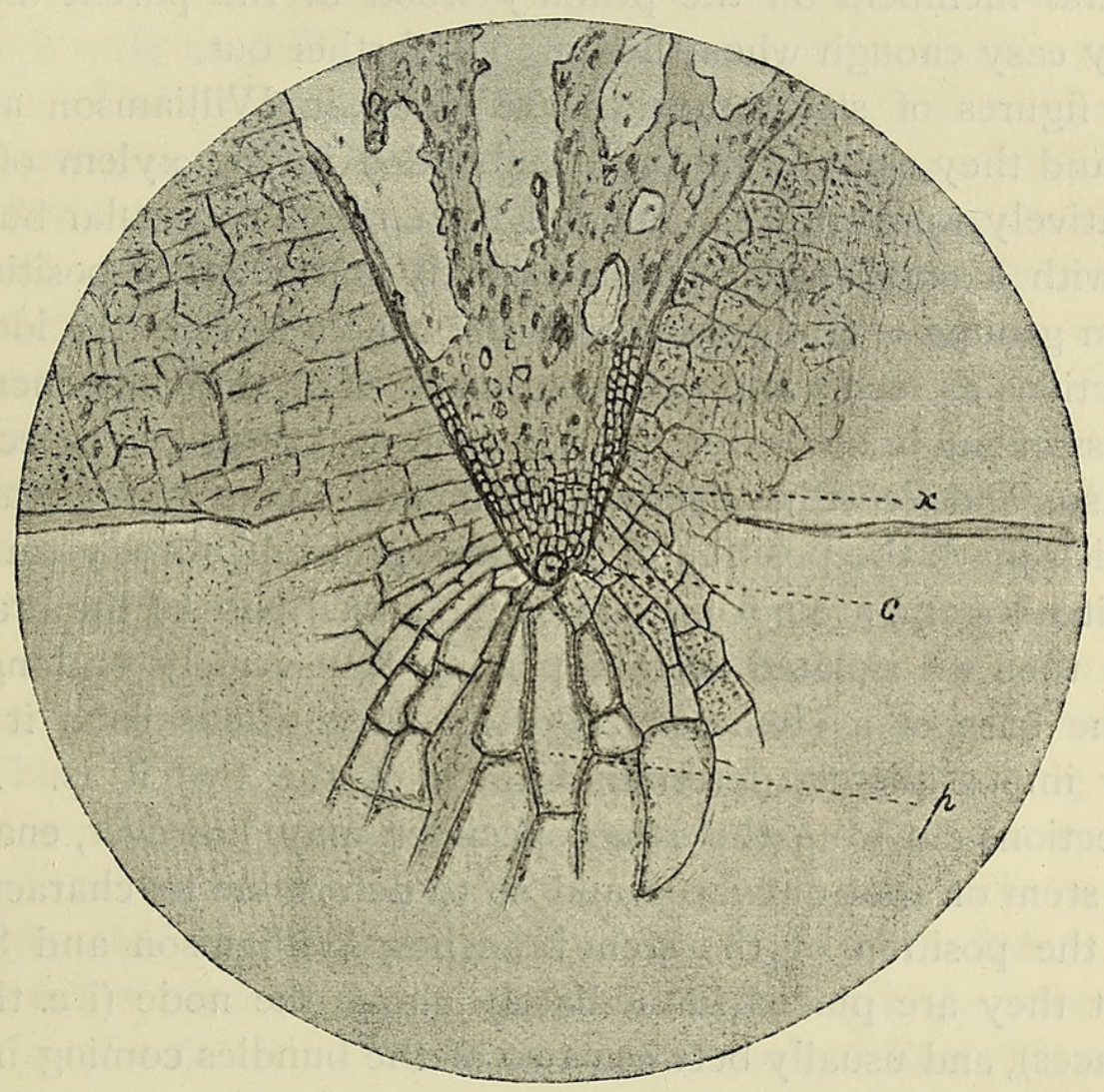

TExt-FIg. I. Part of a transverse section of a stem of Calamites (slide $1095 \mathrm{~S}$ ) showing one of the xylem wedges. $c$, carinal canal; $x$, xylem; $p$, peculiar cells.

fact that the main axis is really a stem of Calamites. The points of the xylem wedges are surrounded by peculiar large cells, which, if in their natural condition, as they certainly appear to be, are different from those of any other Calamite stem with which we are acquainted (Text-Fig. I). In vertical sections these cells are often nearly square in outline. Similar cells can be seen forming the pith of the lateral roots ${ }^{1}$.

The next series of slides $\left(54^{8}-557\right.$ S) consists of nine longitudinal sections and one transverse one made from a flattened stem found by Mr. Lomax in the Halifax Hard Bed. Slide ${ }_{1} 783 \mathrm{~S}$ appears to have been cut from the same block. 
The longitudinal sections are cut parallel to the longer diameter of the transverse section of the flattened stem, and the series passes completely through the xylem of one side, then across the pith and the wood on the other side, and finally into the matrix in which the stem is embedded. The sections pass through one node, and at least five roots can be seen springing from this node. One of the roots branches when it is free from the wood of the main axis.

There is very considerable difficulty in distinguishing the stem-branches from the root-branches in sections which are taken close to the insertion of the lateral members on the primary wood of the parent axis, though it is usually easy enough when they are cut farther out.

Good figures of stem-branches are given in Williamson and Scott's Memoir ${ }^{1}$, and they show, while still embedded in the xylem of the main axis, a relatively wide pith surrounded by a ring of vascular bundles each provided with a small canal (carinal canal) marking the positions of the protoxylem groups. The presence of the canals renders the identification of such sections as stems and not roots easy. The difficulty increases with the nearness of the branches or roots to their seat of origin, especially since, as Williamson and Scott have shown, the characteristic inter-nodal or carinal canals, which mark the position of the disorganized protoxylem groups of the Calamitean stem, are not present at the actual base of the branch ${ }^{2}$.

Given then an isolated section passing transversely or longitudinally through the base of a stem-branch or an adventitious root, it is usually practically impossible to determine which of the two it is. A number of serial sections cut from the same specimen may, however, enable one to follow the stem or root outwards and so to determine its character. With regard to the position of the stem-branches, Williamson and Scott have shown that they are placed immediately above the node (i.e. the level of the leaf-traces), and usually between two of the bundles coming in from the leaves.

Plate I, Fig. 2 (slide $55^{\mathrm{I}} \mathrm{S}$ ) is from a tangential longitudinal section of the stem showing two roots in approximately transverse section. The main axis is evidently a stem as it shows clearly the usual bifurcation of the bundles at the node, leaf-traces (l.t.) passing through the nodal wood, and Williamson's 'infra-nodal organs' (i.n.o.). As the latter always occur below the node ${ }^{3}$ they enable one to orientate the sections correctly, i. e. to distinguish the upper and lower ends. The section is evidently cut near to the pith of the stem, and passes through the inner portion of the wood:

\footnotetext{
1 Further Observations, \&c., Part I, Calamites, Calamostachys, and Sphenophyllum, Phil. Trans., vol. clxxxv, B. I895, Pl. LXXII, Figs. 5 and 6.

${ }^{2}$ Loc. cit., p. 89 I.

${ }^{3}$ Small enlargements at the lower ends of the medullary rays (i. e. above the node) often occur, but these are usually easily distinguished from the infra-nodal organs.
} 
this is clear from the distinctness of the vascular bundles $(x)$ and wide medullary rays $(m . r$.$) . This photograph shows only one of the two roots$ which can be seen in the section (the other one is shown in Fig. 3), but the centre of the one figured $(r$. ) appears to be exactly in a line with the leaftrace bundles (l.t.) of the stem. This is therefore a first point of difference from the stem-branches, which always arise distinctly above the level of the leaf-traces, i. e. above the node.

Fig. 3 is made from the same slide as Fig. 2, but it shows the other root which is coming from the same node, and is more highly magnified than the latter. This photograph shows clearly two of the stem-bundles $(x . x$.) with a wide medullary ray $(m . r$.) between them and a root $(r$. $)$ at the node above. The section becomes more tangential in the upper part, and the root shows the connexion with the secondary xylem of the stem above and with the nodal wood below. The position of the root with reference to the bundles of the stem is quite clear. It lies midway between the two bundles which are coming up from below, and indeed, in this respect, occupies precisely the same position as the stem-branches. This will be clearly seen by comparing our Fig. 3 with similar sections of stem-branches given by Williamson and Scott. The similarity of the two is very striking ${ }^{1}$. As the vascular bundles in the stem of Calamites usually alternate in position in successive internodes, it follows that both branches and roots will usually be opposite to a bundle in the internode above the node from which the lateral member springs, but opposite to a medullary ray of the internode below. This difference may be made use of in determining whether a transverse or oblique section of a stem which also shows one or more roots is cut above or below the node from which the roots arise. It is clear, for example, that the sections from which Figs. 9, Io and II (Plate II) have been made were cut below the node from which the root shown was developed, as the centre of the root is in a straight line with a medullary ray of the stem and not with one of its vascular bundles. That the stem-bundles of successive internodes do not always regularly alternate is well known, and indeed an example of it is shown near the centre of Fig. 2, but it is sufficiently constant to make this method of some value.

Fig. 3 does not clearly show leaf-trace bundles quite close to the root, i. e. as close to the root as they are shown to the stem-branches in some of Williamson and Scott's figures. Could they be seen, they would probably appear at the sides of the root instead of distinctly below it, as is the case with the stem-branches. The evidence for this statement is as follows. Although no leaf-traces can be made out quite close to the root shown in Fig. 3, they are clearly seen in other parts of the section, and on the same node as that from which this root arises: the centre of the latter is exactly

1 Compare, for example, our Fig. 3 and Williamson's figure showing a stem-branch reproduced in Dr. Scott's Studies in Fossil Botany, Fig. 9, p. 30. 
in a line with the outgoing leaf-traces, thus confirming the evidence of the root shown in Fig. 2. Moreover, if a comparison is made of similar sections showing lateral branches and roots (e.g. Fig. 3 and Williamson's figure ${ }^{1}$ ), it will readily be seen that whereas the branches are well above the node and consequently a considerable distance above the level of the infra-nodal organs, the roots are at the node and within a much shorter distance of the infra-nodal organ of the medullary ray immediately below.

Fig. 4 is from a slide $\left(55^{2} \mathrm{~S}\right)$ cut from the same specimen as that from which Figs. 2 and 3 were made. The section is tangential of the main stem as before, but is cut farther out in the secondary xylem, as is shown by the continuous character of the wood $(x . s$.$) , which is only broken by the infra-$ nodal organs shown at i.n.o. The slide shows the same two roots as before (as well as traces of others from the same node), and one of these is seen in the photograph. The roots are now farther out in the wood; they show the usual 'Astromyelon' structure, and there is no doubt as to their root nature. Comparing this figure with Figs. 2 and 3 it will be seen that the root is somewhat lower, for whereas in the latter sections the roots are distinctly above the level of the infra-nodal organs (i.n.o.), in Fig. 4 the centre of the root is about in a line with them. The root, therefore, probably sank a little in its passage through the secondary wood of the stem.

Fig. 5 (slide $553 \mathrm{~S}$ ) is also from the same specimen, and the slide shows the same two roots. The latter are now still farther out, and the one figured is nearly free from the wood of the parent axis. Its root structure is now very clear.

There can be no doubt then that Figs. 2, 3, 4, and 5 represent roots arising on a stem and apparently exactly at a node of the latter. The differences between the stem and root branches will be clearly seen by comparing our figures with those in Williamson and Scott's Memoir on the stem $^{2}$. The latter figures show that the stem-branches arise considerably above the outgoing leaf-trace bundles, and that they soon develop the characteristic protoxylem canals which are quite absent from the roots.

The next figures are from sections cut from another specimen. This was collected by Mr. Knott at Fieldhouse Colliery, Huddersfield, and is a decorticated stem from one and a half to two inches in diameter, and about five inches long. It is clearly the basal portion of a stem, as it shows several verticils of adventitious roots. The block has been cut into no less than forty-six longitudinal and transverse sections by Mr. Lomax. Fig. 6 is from one of the longitudinal sections of this series (slide I I M). The stem $(s$.$) is cut radially, and medullary rays (m . r$.$) are clearly seen passing$ through the secondary wood. The section also passes radially through a large root $(r$.$) , which sinks gradually in its passage outwards. The con-$ nexion of the pith of the root with that of the stem can be seen. William-
1 Loc. cit.
2 Loc. cit.
Further Observations, \&c., Part I, Pl. LXXII, Figs. 5 and 6. 
son and Scott have shown that in the stem-branches of Calamites the pith terminates inwards in a narrow neck, by which it is continuous with the pith of the stem $^{1}$, and Williamson long ago accounted for the insertion of the medullary casts of large branches on their stems by means of a narrow neck, by the narrowing of the pith ${ }^{2}$. Our Fig. 6 shows that the narrowing of the pith inwards also takes place in the roots. Judging from this section, however, and comparing our Fig. 6 with the figures of stem-branches given by Williamson and Scott, it appears that in the roots the narrowing is more gradual than in the stems. Comparison of stem and root branches which are cut approximately at the same distance from the centre of the main axis on which they are borne, but so as to avoid the narrow neck connecting them, shows that the stem-branches have a relatively larger medulla. Compare our Figs. 2, 3, and 4, and Williamson and Scott's Figs. 5 and 6.

It is well known, however, that specimens of Astromyelon vary greatly in the relative size of the pith, which may consist of very few cells indeed, so that they can hardly be identified, or it may be relatively large. This extreme variation in size of the medulla is not found in the roots which arise directly on the stems and with which we are here specially concerned, but only in the smaller specimens. Of these there are many scattered through our slides, and they doubtless result from the branching of the larger roots, all of which agree in the possession of a well-developed pith.

Fig. 6 also shows the connexion of the primary and secondary xylem of the main axis with those of the root.

Figs. 7 and 8, Plate II (slides 5 and $7 \mathrm{M}$ ) are made from sections cut from the same specimen as Fig. 6 , but they do not pass through the same root.

The section from which Fig. 7 is taken is cut longitudinally, and it passes into the pith of the stem. The figure shows a medullary ray $\left(m_{0} r_{0}\right)$, and one of the infra-nodal organs $(i . n . o$. $)$. Just above the level of the latter, part of one of the nodal diaphragms is preserved $(n . d$.$) , and in a line$ with this a leaf-trace bundle can be seen in the section. The leaf-trace can hardly be made out in the photograph, although easily seen in the section; its position is indicated at l.t. A root $(r$.$) is shown, and its centre$ is about on a level with the leaf-trace bundle and the nodal diaphragm.

Fig. 8 shows the same root as the last, but it is cut nearer its origin, just above an infra-nodal organ $(i . n . o$.$) . In both of these cases, as well as$ in Fig. 6, the central part of the pith has disappeared. There is some evidence in these cases that the disappearance is due to fungal action.

The usual persistence of the pith in Astromyelon was one of the

1 Loc. cit., Pl. LXXX, Fig. 22.

${ }^{2}$ See Organization of the Fossil Plants of the Coal Measures, Part IX, 1878, Phil. Trans.o Pl. XXI, Fig. 30 and description of the same. 
characters which led Williamson to separate it from Calamites (i.e. the root from the stem), and the smaller specimens usually agree in the possession of a solid medulla either relatively small or large. In the larger examples, however, those which arise directly on the stems, the disappearance of the central part of the pith is usual, and there is often a definite line separating the central cavity from the peripheral persistent portion. The latter always forms a wide band of tissue, and the pith never disappears right up to the xylem as is usually the case in the larger stems.

Some slides that we have serve to throw some light on this subject.

Fig. 9 (slide $\mathrm{I} 685 \mathrm{~S}$ ) is from an approximately transverse section of a stem which is evidently cut near to (just below) a node, as some infranodal organs $(i . n . o$.) are passed through. A root is shown passing out obliquely through the secondary wood $(s . x$.) of the stem. This root must have passed out much more obliquely than those shown in Figs. 2, 3, 4, 5, and 6 , since although the stem is cut nearly transversely the root is also cut more nearly transversely than longitudinally. The connexion of the wood of the root with the secondary xylem of the stem is clearly seen, as well as the contortion of the tracheides (c.t.) on the inner side of the root. The pith of the root is here quite entire, but it shows a well-marked differentiation into a small central portion $(c . p$.$) of thin-walled cells and$ a wide peripheral zone $(\not, p$.$) in which the cells appear to have had thicker$ walls.

Fig. Io shows a portion of Fig. 9 more highly magnified. The differentiation of the pith and the contortion of the tracheides are more clearly shown.

Fig. II (slide I 748 S) is from a slide cut from the same specimen as Figs. 9 and 10. The root is now farther out, and the central portion of the pith is represented by a space, owing to the destruction of the thinnerwalled tissue.

Fig. I2 (slide $22 \mathrm{M}$ ) shows a root cut quite close to its origin. The connexion of the primary and secondary wood of the stem with those of the oot can be seen, and also clear differentiation of the pith into an outer thicker-walled zone $(p . p$.$) and a thinner-walled central portion (c.p.).$ In other sections showing the same root cut farther out from the axis the central part of the pith is hollow.

The differentiation of the pith is visible in a large number of the sections at our disposal, and in nearly all cases the central portion becomes hollow while the root is still embedded in the parent stem. In some cases there is no evidence to show that the destruction of the central cells was other than a natural process, but in other cases fungal action appears to have caused or helped in the disintegration. It may be that the walls of the inner cells were composed of cellulose, while those of the outer part were more or less lignified and so were able to resist fungal action. 
On the whole, we incline to the opinion that the larger adventitious roots of Calamites, i. e. those which spring directly from the stems, were probably fistular, and the presence of thinner-walled central cells would indicate that this may have been their natural condition. A few of our specimens form an exception to this rule. The sections from which Figs. $2,3,4,5$ are taken show roots originating directly from a stem, but the pith of the former is neither differentiated nor hollow. This may be a specific distinction.

This paper is not specially concerned with the smaller roots of Calamites, of which there are many scattered through our sections, and which are mainly branches of roots and not borne directly on stems. These are the specimens usually figured by Williamson, and by Williamson and Scott. The medulla varies enormously in relative size, and is sometimes absent altogether. As usually developed, the pith-cells show a gradual increase in size towards the centre, but no differentiation into distinct outer and inner portions such as is commonly seen in the larger roots, and there is no evidence that the pith became hollow. The presence or absence of a pith in these small specimens of Astromyelon appears to be an individual variation, or it may vary in the same individual. A curious case is illustrated in Fig. ${ }_{3}$ (slide $48 \mathrm{M}$ ), which shows a small branching specimen in which the branch has a conspicuous pith while the parent axis has none.

\section{SummaRy AND CONCLUSIONS.}

The roots of Calamites were mainly adventitious, and they usually arose in whorls from the nodes of the lower portion of the aerial stems as well as from the underground rhizomes.

The lowest portion of the ascending stems rapidly tapered to their insertion, probably, on the underground rhizome. The actual connexion was probably a small one. The roots arise in direct connexion with the protoxylem of the main axis, and are not seated on the bases of the branches as in Equisetum. Detailed examination of this large sertes of sections affords no evidence of any connexion between the roots and the infra-nodal organs of Williamson. Roots and stem-branches are difficult to distinguish from one another in sections which are cut quite near to their insertion on the protoxylem of the main axis. The roots resemble the stem-branches in their position relative to the stem-bundles and the outgoing leaf-traces, as seen in tangential sections through the main stem, i.e. in both cases the lateral member is usually placed so that its centre lies vertically above a medullary ray of the internode below and between two leaf-traces.

The roots arising directly on the stems appear to differ from stembranches in the following particulars:- The roots arise on a level with 
the leaf-trace bundles, i. e. at the node, and not above them as in stembranches; the roots pursue a somewhat downwardly directed course in passing through the wood of the main axis (the actual angle of divergence seems to vary greatly in different cases); the internodal (carinal) canals, representing the disorganized protoxylems, which are characteristic of the stem-branches even when embedded in the wood of the main axis, are not present in the roots; the narrowing of the pith of the root before it joins with that of the stem appears to be more gradual than in the stem-branches, otherwise they appear to be very similar to one another, and there is usually a differentiation of the pith into distinct inner and outer regions. The pith of the large roots usually became hollow by the destruction of the thinner-walled central portion. In nearly all cases there is a wide band of persistent pith, i. e. the whole of the pith does not usually disappear as in the larger stems.

In conclusion, I wish to express my obligation to Dr. D. H. Scott, M.A., F.R.S., who suggested the investigation and supplied the slides on which the work is based. He has also allowed the work to be done in the Jodrell Laboratory at Kew, and has kindly afforded much help during its progress. My thanks are also due to Mr. L. A. Boodle, F.L.S., for great assistance in connexion with the photographs which accompany this paper, and to Mr. W. W. Midgley, F.R.Met.S., who kindly supplied the photograph from which Fig. I (Pl. I) is made.

\title{
EXPLANATION OF FIGURES IN PLATES I AND II.
}

\author{
Illustrating Mr. Maslen's paper on 'The Relation of Root to Stem in Calamites.'
}

PLATE I.

Fig. I. The basal part of an upright stem of Calamites, showing nodes with whorls of adventitious roots coming from the stem. The arrows indicate the position of the nodes.

Fig. 2. Part of a tangential longitudinal section of a stem of Calamites (55 I S), showing a root $(r$.$) in approximately transverse section. l.t., leaf-traces; i.n.o., infra-nodal organs; x$., vascular bundles of stem; m.r., medullary rays.

Fig. 3. Another portion of the same section as that from which Fig. 2 is made, showing another root from the same node. $x . x_{\text {. }}$, two stem-bundles; $m . r_{\text {. }}$, medullary ray; $i . n . o$. , infra-nodal organ ; r., root.

Fig. 4. Another tangential section from the same block as Figs. 2 and 3. r., root; i.n.o., infranodal organs. Slide $55^{2} \mathrm{~S}$.

Fig. 5. Another section showing the same root. $x_{.}$s., xylem of stem; $x . r$, xylem of root; $p$., pith of root. Slide $553 \mathrm{~S}$.

Fig. 6. Radial section of a stem of Calamites also passing radially through a root. s., stem; $m . r$. , medullary rays of stem; s. $p$. , pith of stem; $r$, root; $r . p$. , pith of root. Slide I I M. 


\section{PLATE II.}

Fig. 7. Longitudinal section cut from the same block as Fig. 6. m.r., medullary ray of stem; i. n.o., infra-nodal organ; $r$, root; l.t., position of leaf-trace bundle; $n . d$. nodal diaphragm. Slide $5 \mathrm{M}$.

Fig. 8. Another longitudinal section from the same block as Figs. 6 and 7 , and showing the same root as Fig. 7. r., root, $i, n . o$., infra-nodal canal. Slide $7 \mathrm{M}$.

Fig. 9. Approximately transverse section of a stem of Calamites with an included root. i.n.o., infra-nodal organ; s. $x$., secondary xylem of the stem; c.t., contorted tracheides on the inner side of the root; $c . p$., central part of the pith of the root; $p . p$., peripheral pith of the root. Slide $1685 \mathrm{~S}$.

Fig. Io. A portion of Fig. 9 more highly magnified. Letters as before.

Fig. II. Another approximately transverse section from the same block as Fig. 9. The root is now farther out. $c . p$., central pith of root; $p$. $p$., peripheral pith of root. Slide $1748 \mathrm{~S}$.

Fig. I2. Oblique section of a stem of Calamites, showing a root cut quite close to its origin. $c . p$., central pith of root ; $p$. $p$., peripheral pith of root. Slide $22 \mathrm{M}$.

Fig. I3. A small branching root of Calamites, showing a pith-less specimen bearing a branch with a distinct pith. $x . m$., xylem of main axis; $x . b$., xylem of branch; $p . b$, pith of branch. Slide $48 \mathrm{M}$. 
Fig. 2.

Fig.1.

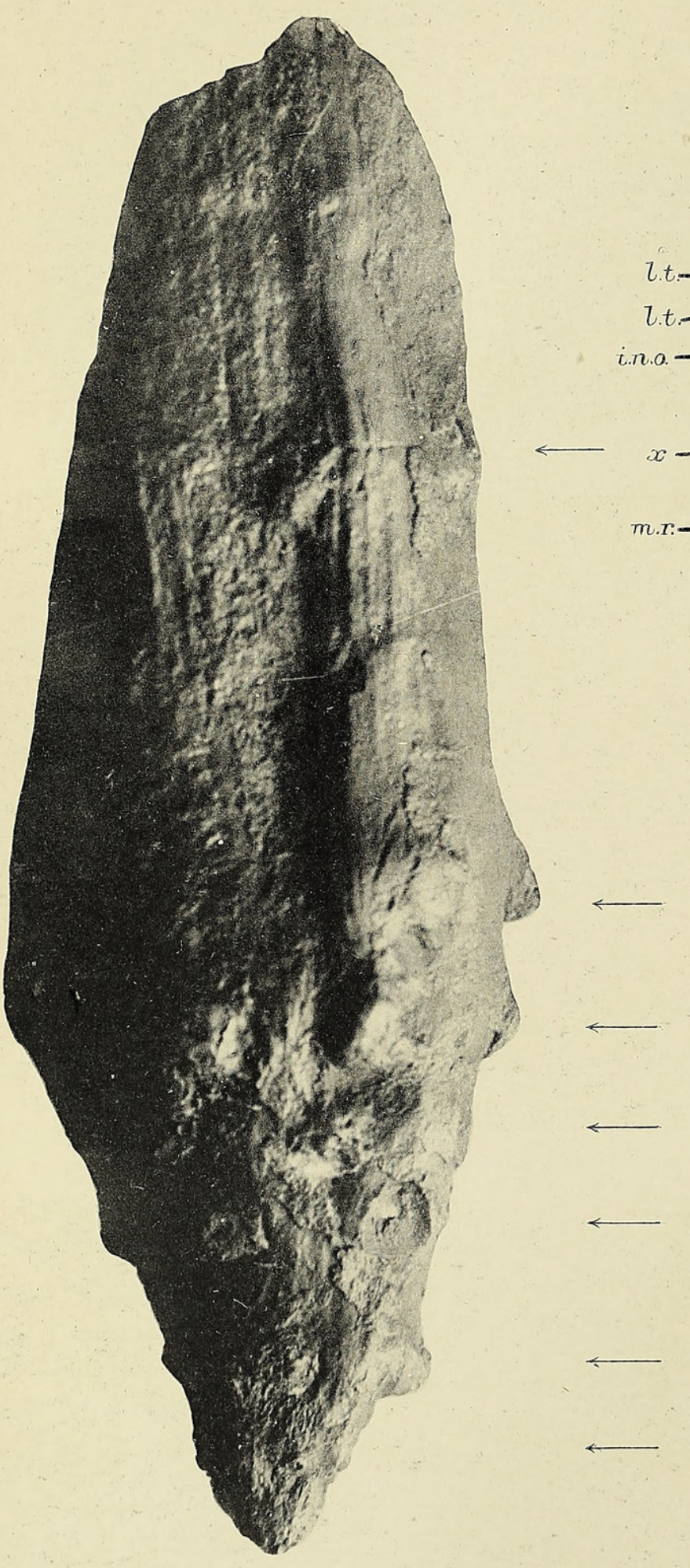

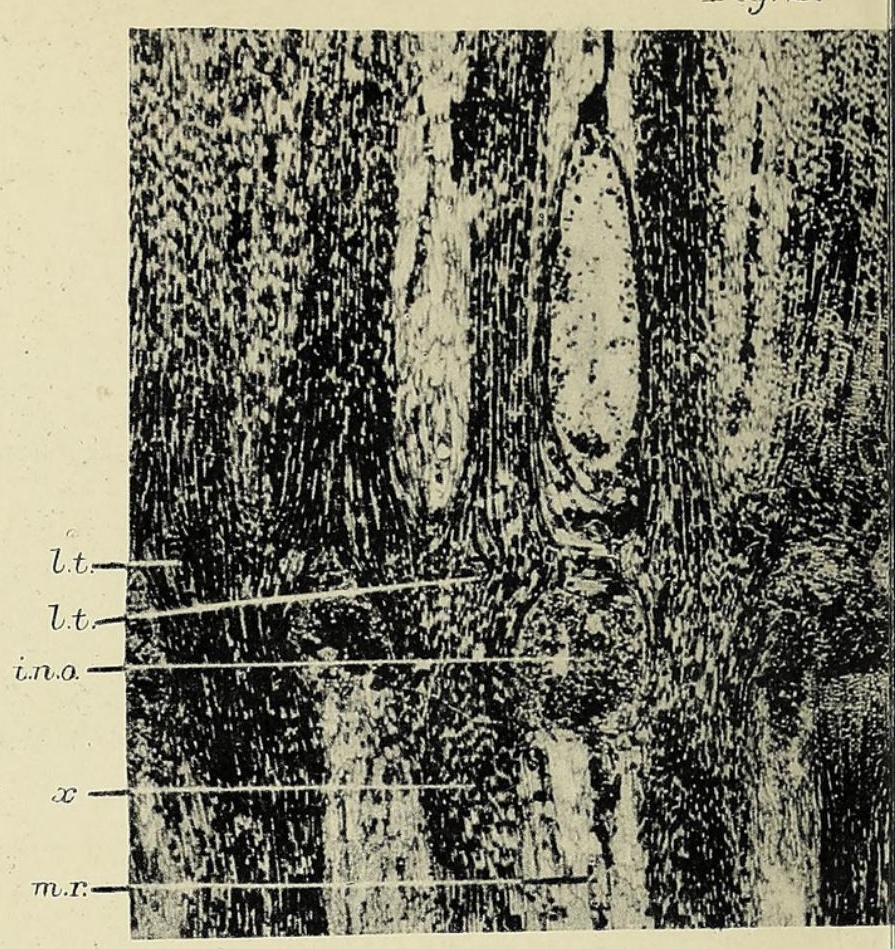

Fig. 3

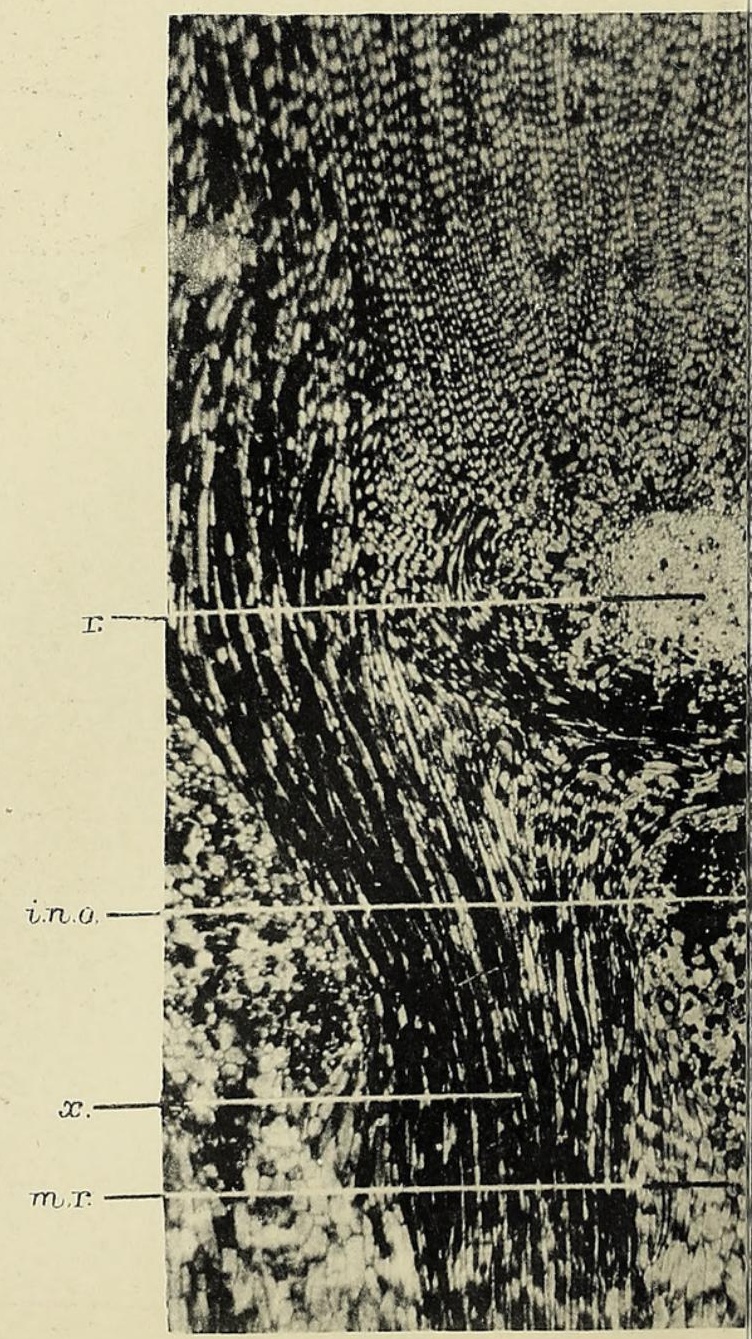


Fig. 2 .

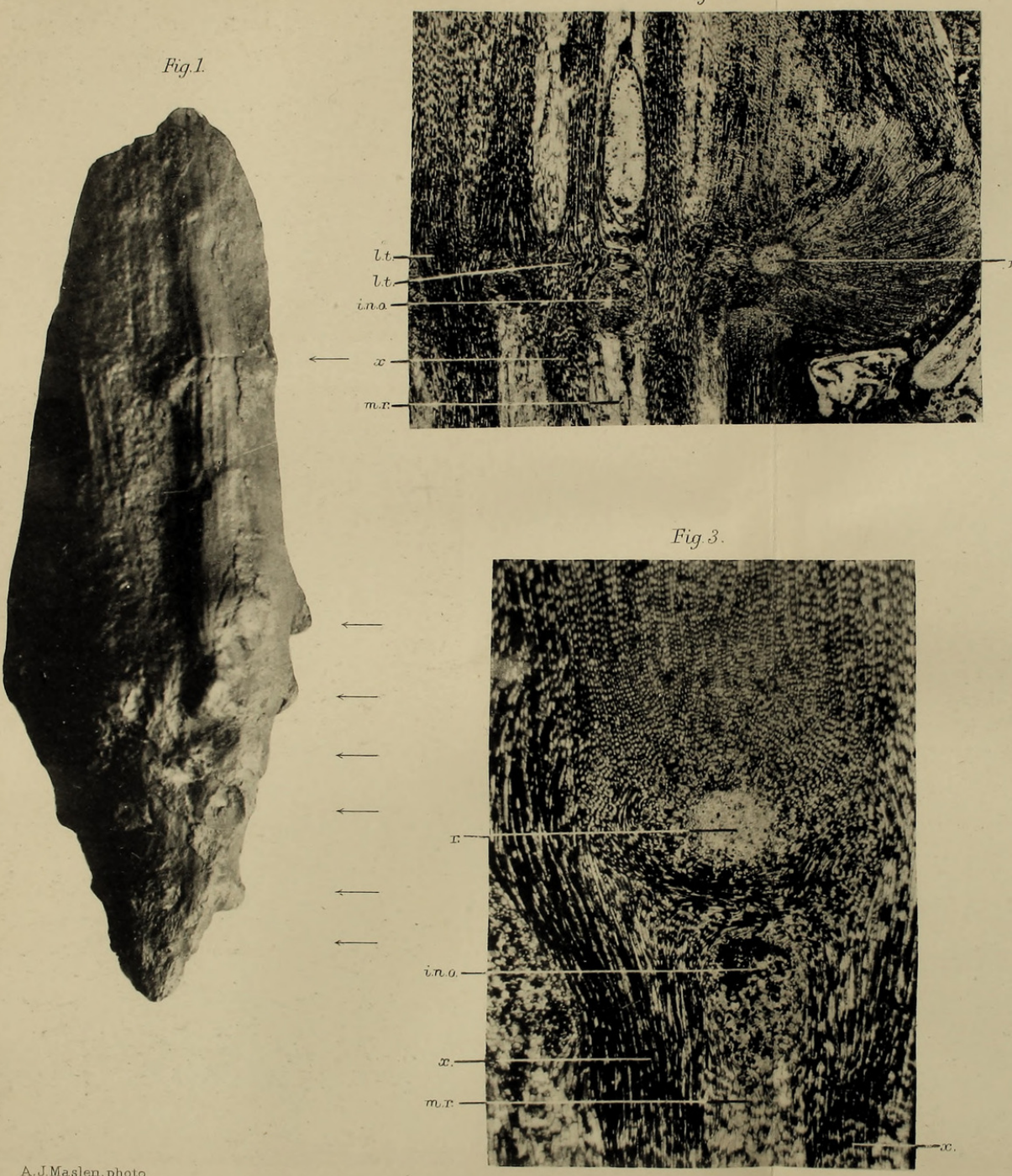

Fig. 4.
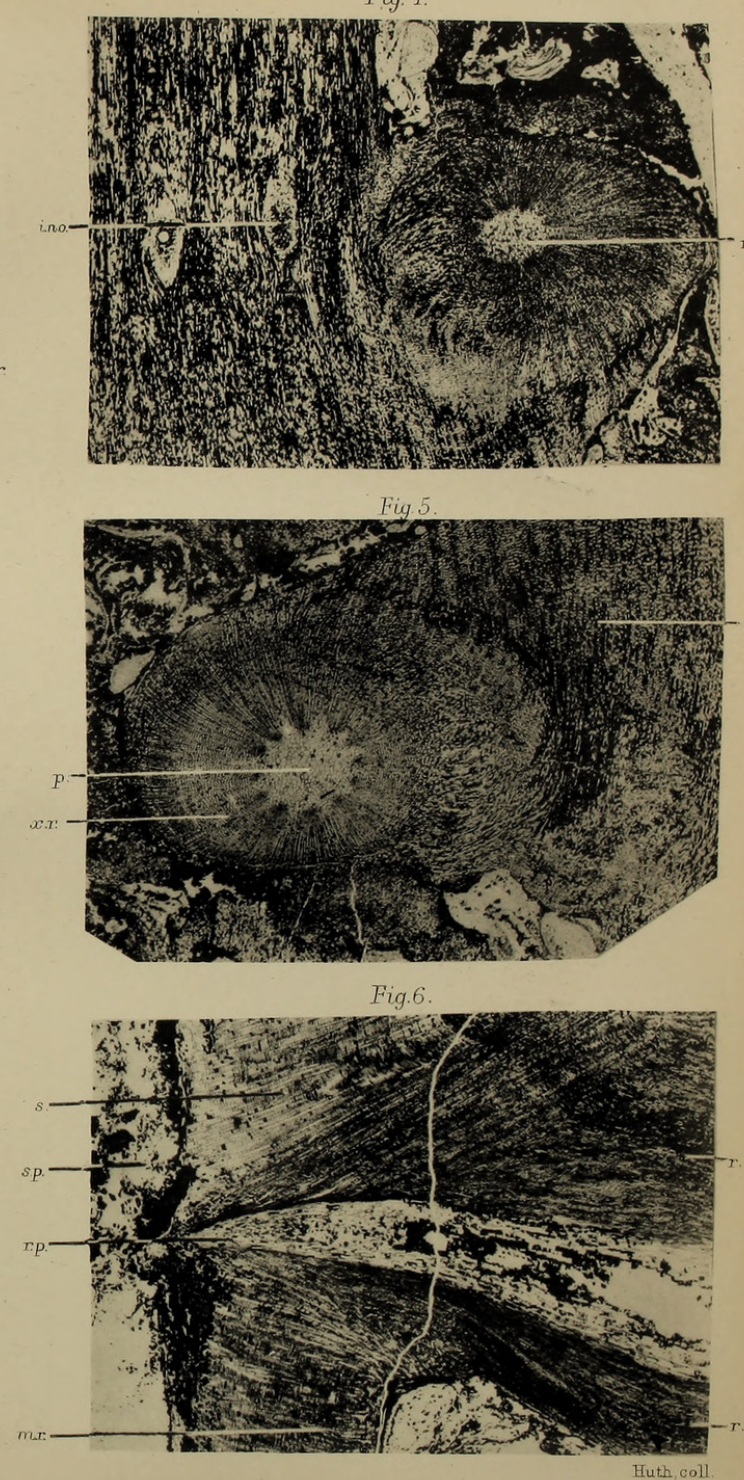

MASLEN - ON ROOTS OF CALAMITES 
Fig.7.

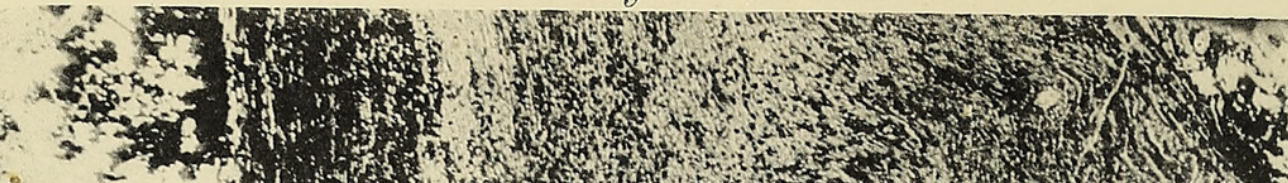

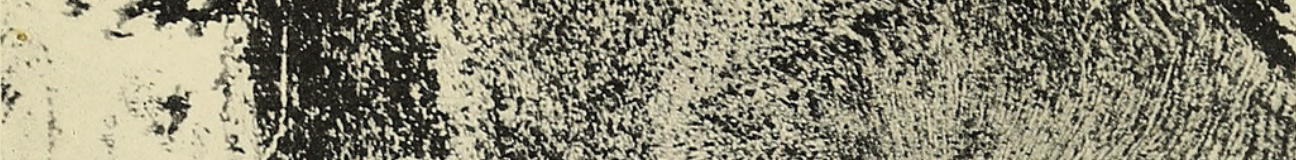

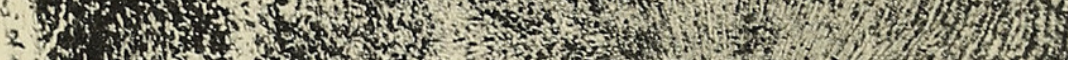

1.

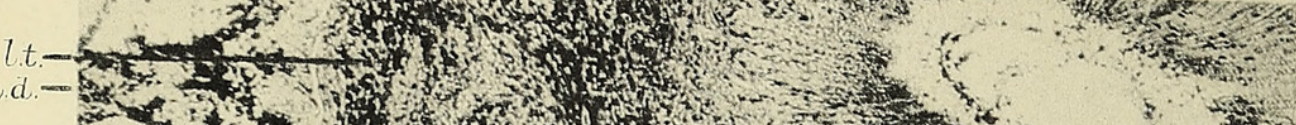
2.4

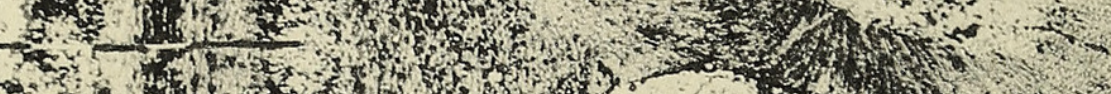

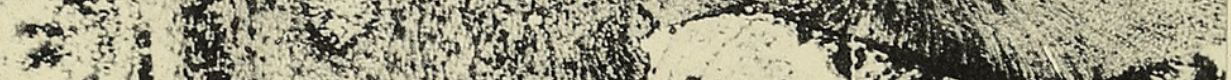

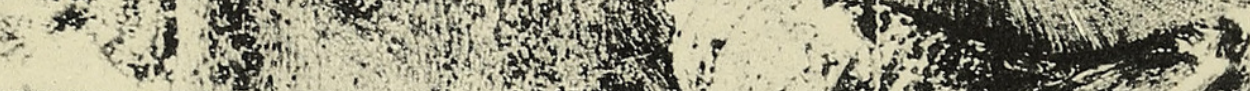
- Mon

Fig.11.

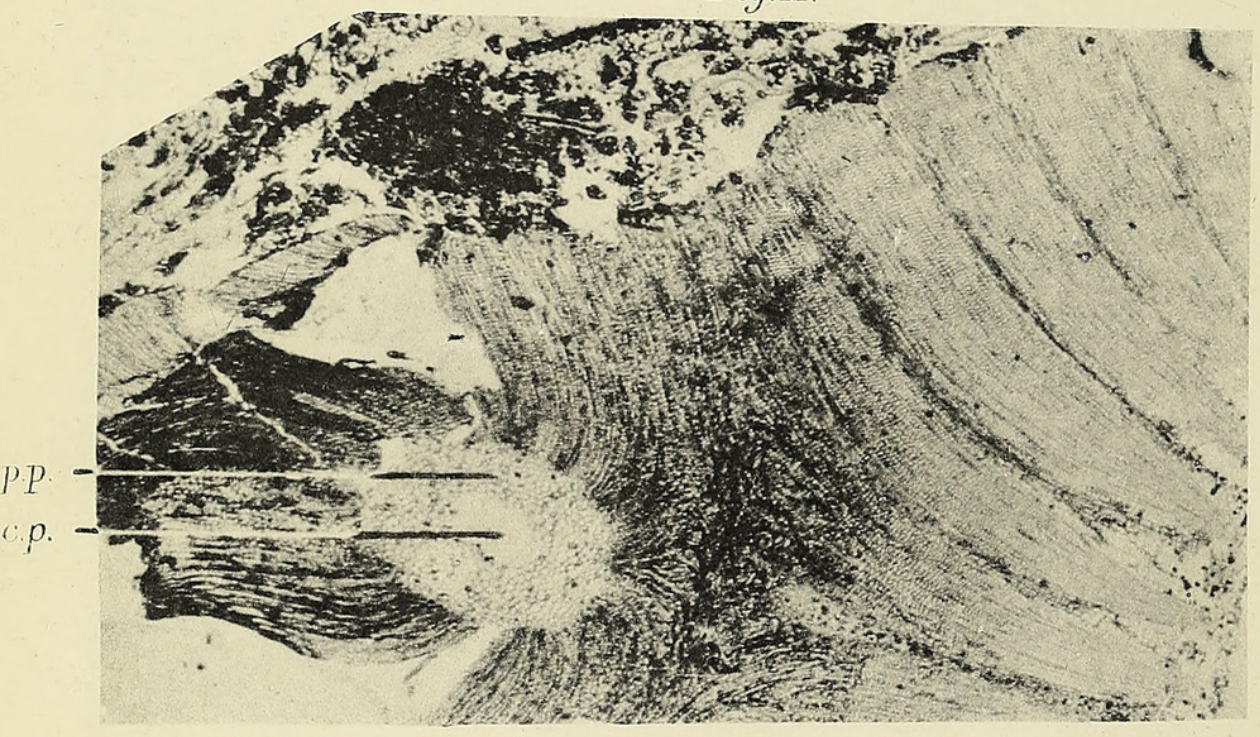

\section{Fig.9}
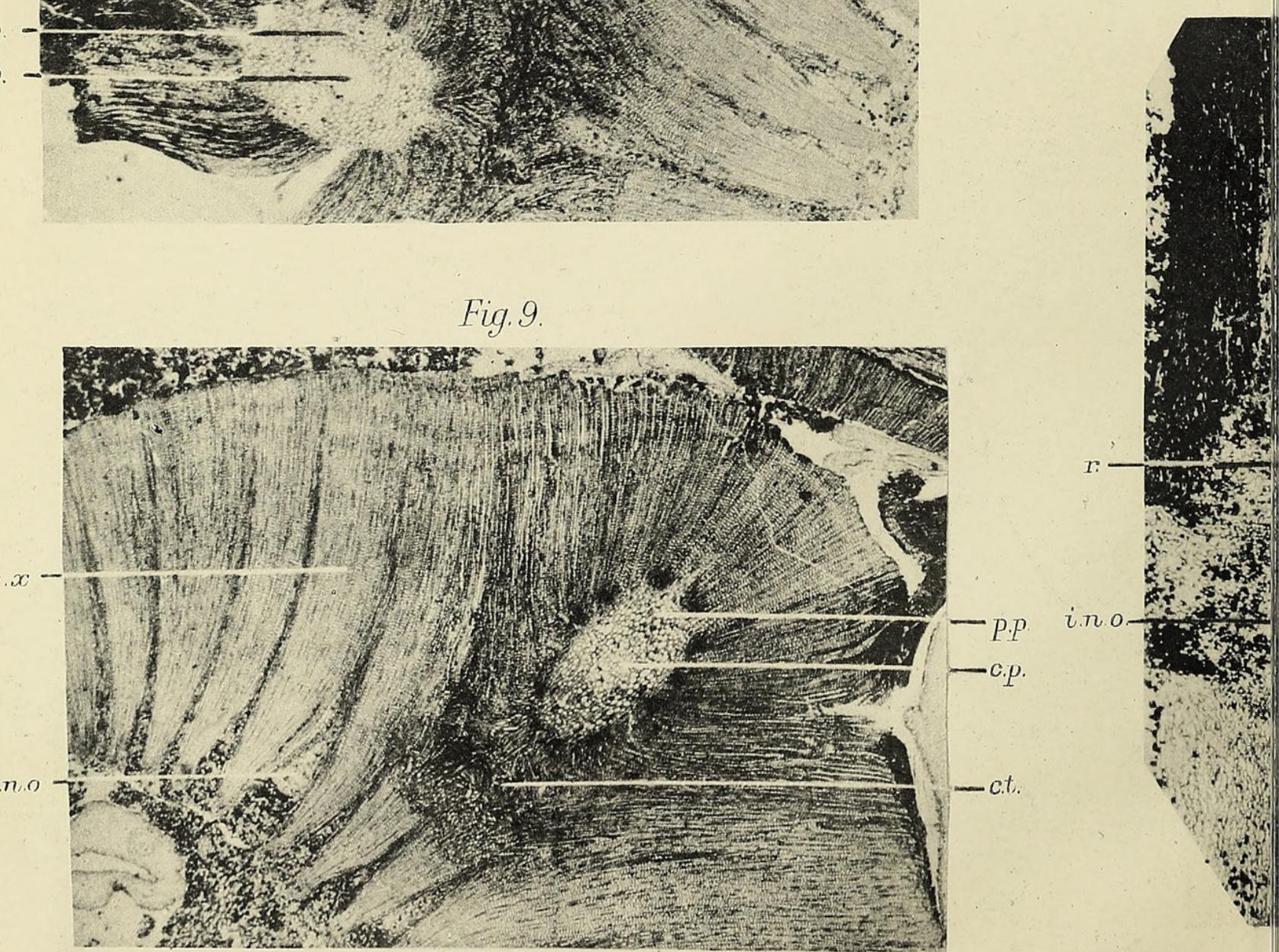

A.J.Maslen, phot 


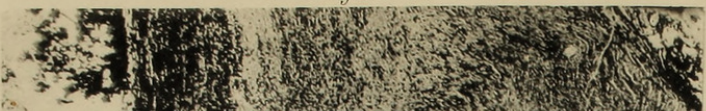

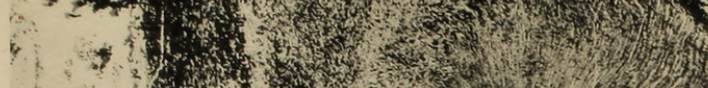

-

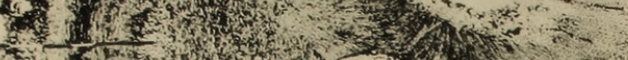

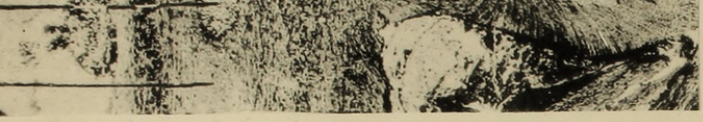

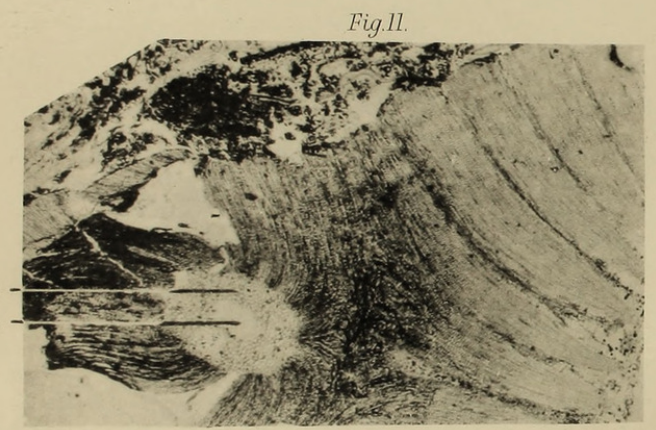

Fig. 9
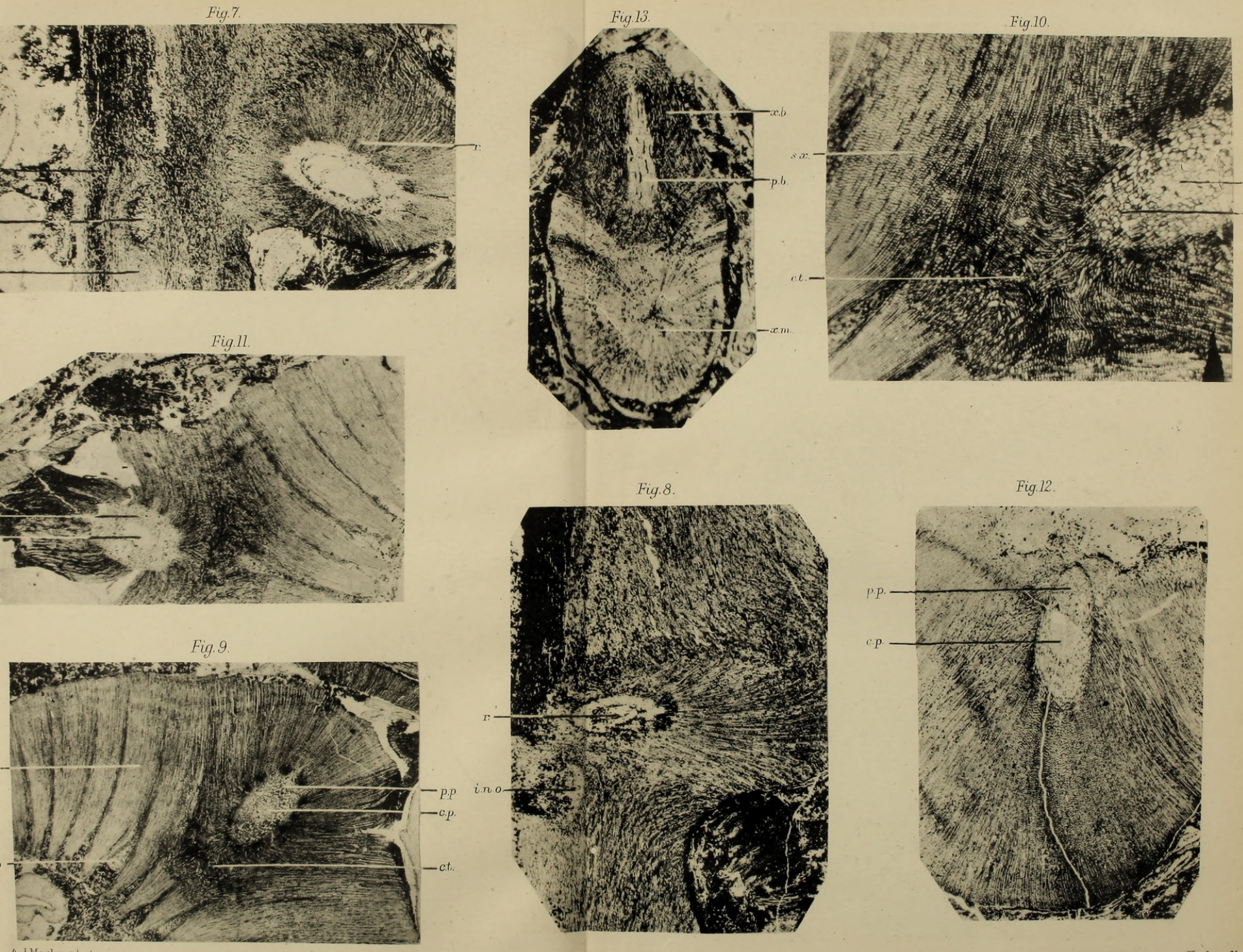

Fig. 8

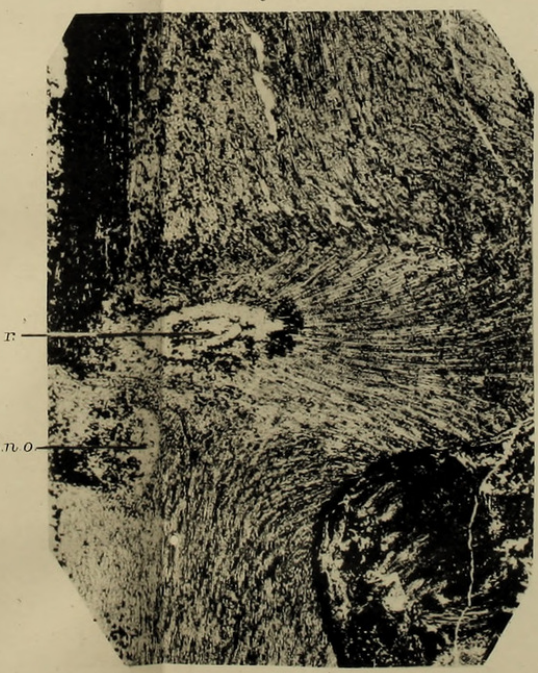

Fig.12.

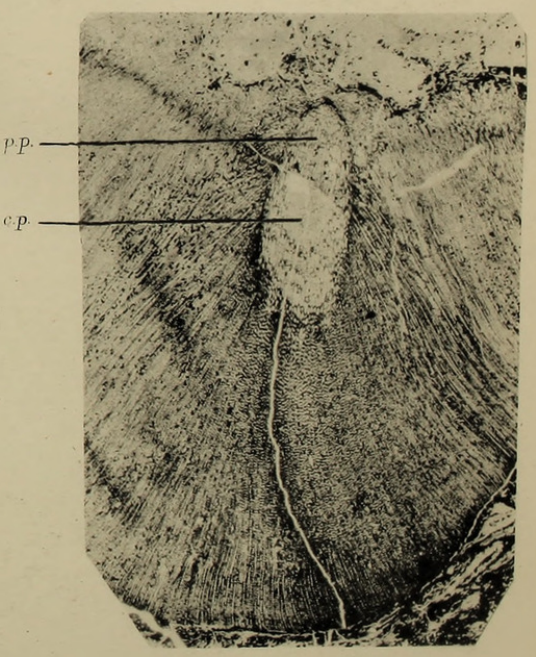




\section{$2 \mathrm{BHL}$ Biodiversity Heritage Library}

Maslen, Arthur J. 1905. "The relation of root to stem in calamites." Annals of botany 19, 61-73. https://doi.org/10.1093/oxfordjournals.aob.a088993.

View This Item Online: https://www.biodiversitylibrary.org/item/233541

DOI: https://doi.org/10.1093/oxfordjournals.aob.a088993

Permalink: https://www.biodiversitylibrary.org/partpdf/318785

\section{Holding Institution}

Smithsonian Libraries

\section{Sponsored by}

Biodiversity Heritage Library

\section{Copyright \& Reuse}

Copyright Status: Not in copyright. The BHL knows of no copyright restrictions on this item.

This document was created from content at the Biodiversity Heritage Library, the world's largest open access digital library for biodiversity literature and archives. Visit BHL at https://www.biodiversitylibrary.org. 